\title{
The Role of the Railway in Regional Development in Austro-Hungary and in Hungarian-Croatian Relations Today, Especially with Regard to the Availability of Rijeka (Fiume) ${ }^{1}$
}

\author{
Lóránt BALI
}

\author{
Vállalatökonómai és Vidékfejlesztési Tanszék, \\ Georgikon Kar, Pannon Egyetem \\ Department for Corporate Economy and Regional Development, \\ Faculty of Georgikon, University of Pannonia \\ Deák Ferenc u. 16, 8360 Keszthely, Hungary \\ balilori@georgikon.hu
}

\section{Introduction}

In the following study I will investigate the Carpathian-Balkan region as a single socio-economic space, in which the Austro-Hungarian Monarchy has always been a significant actor. In the dualist state Hungary was concerned especially in the food industry and the development of agriculture. It was important for our country to reach foreign markets, which was made possible by the joint development of rail and sea transport. After the Treaty of Trianon the region restructured significantly. This is true with specific reference to Yugoslav-Hungarian relations. Until the end of state socialism these could be characterized with markers like "alienated" and "existing side by side". Over the past twenty years, even before the Treaty of Trianon these markers have changed to "mutually cooperative" or "partially integrated". This situation will most likely stand back and will be preserved. By re-integration the area becomes an integral part of the European economic space again, as well as in the second half of the $19^{\text {th }}$ century. Our goal is to introduce the role of the railway (the so-called "iron horse") in the past and today.

"For Hungary the second half of the $19^{\text {th }}$ century, namely the turn of the century, was a really unique period. While elsewhere in Europe emerging socio-economic conditions and processes occurred at different times, in our country they occurred at the same time, and whilst elsewhere the process of events took a long time, for us it was a relatively short period of time. The terms and conditions of the civilian social system were built with almost one single act (the so-called. "Laws of April," in 1848), and in the middle of the $19^{\text {th }}$ century the first wave of the industrial revolution reached our country (for example: steamboat, railway construction, the first manufacturing plants, etc.) moreover national independence (limited) with a slight delay (1867 Compromise) was also a strong inspiration to the changes and the international economic situation also hastened Hungary's economic convergence (agricultural prosperity, capital surplus, the superabundance of products made by mass 
production and liberal economy policies etc.). ${ }^{2}$ The creation of a high-quality fixed-line infrastructure was an inevitable condition of the economic convergence. From the point of view of the area I study, great attention must be paid to the railway and the Drava River as a waterway as well as to Fiume as a sea exit of the Hungarian Kingdom. These factors were those that promoted the interior and external trade of agricultural products.

\section{The Development of the Railway Infrastructure}

A crucial factor in the socio-economic development was the "iron horse", whose effects were multiplied by the existence of rail near ports as well as the attached superstructures. In our country the configuration of those railroads had started even before the Compromise period, which later played an important role in approaching Fiume today's Rijeka. In the wider area Nagykanizsa, Pécs, Barcs, Osijek, ${ }^{3}$ Subotica, ${ }^{4}$ Szeged and Oradea ${ }^{5}$ played an important role from the point of view of the railway.

For the first time it was the 1836 Act that regulated the future building of railways and this Act described "the route between the capital, Pest and the Hungarian port. The Parliament of 1843 considered the Pest - Eszék (Osijek) - Zimony (Zimun) line and the Lower Tisza region-Osijek coastal line as workable on a state budget. The same parliament adopted a bill on the construction of a railway between Osijek or Vukovar and Károlyváros (Karlovac)."6

\section{Figure 1. The Railway Network Development Plan of Minister Imre Mikó}

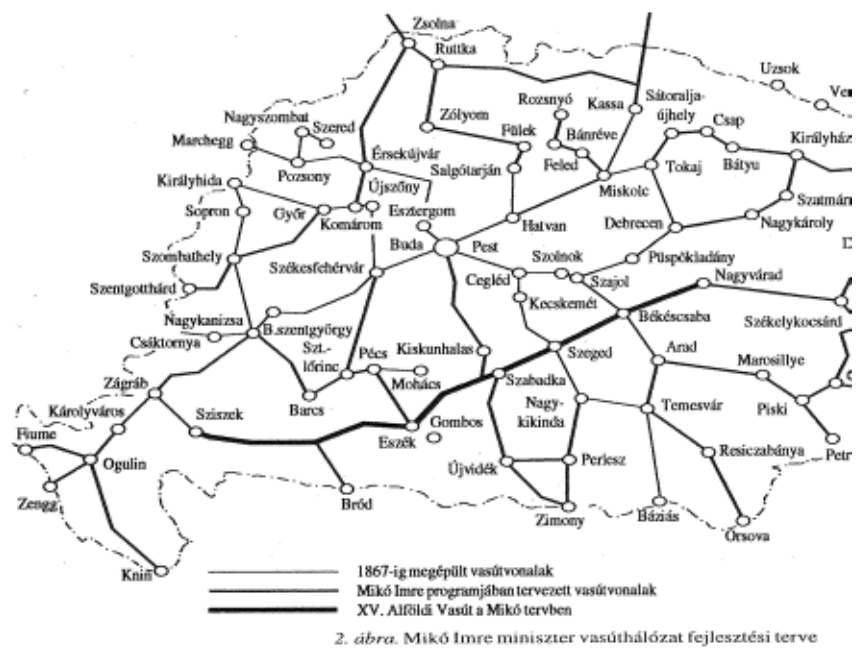

Source: Horváth 1995, 235.

2 Pál BELUSZKY, Őrség-Vendvidék Felső-Rába-Völgye: Szentgotthárd és Környéke, Budapest-Pécs $2005,64$.

3 In Hungarian known as Eszék.

4 In Hungarian known as Szabadka.

5 In Hungarian known as Nagyvárad.

6 Ferenc HORVÁTH, 125 éves a volt Alföld-Fiume Vasúttársaság Nagyvárad-Eszék-Villány vonala, in: Vasúthistória Évkönyv, Budapest 1995, 233-278. 
The railway construction started in 1860 in the area with the Nagykanizsa - Pragersko ${ }^{7}$ section of the Southern Railway, followed by the Buda - Nagykanizsa line in 1861 and in 1865 the Sopron - Nagykanizsa line. By these investments primarily Nagykanizsa got into a good geographical position. Later on, the city became the gate towards the direction of Vienna and Trieste. First the construction of main lines took place which ensured the connection to the capital and the western regions of the Empire. The construction of sections switching the South-Transdanubian region in the network began after the Compromise. In 1868 the establishment of the Pécs - Barcs line began and in the same year the Barcs - Nagykanizsa line was opened as well. For both imperial and local interests the main objective was to further expand the existing network in the south-eastern direction connecting the southern and lowland areas. ${ }^{8}$ As the fourth beat of the Great Hungarian Plain-Fiume Railway the Villány - Osijek - Dalj ${ }^{9}$ - Богојево / Bogojeva ${ }^{10}$ - Сомбop / Sombor ${ }^{11}$ а 133-kilometer line was established. ${ }^{12}$ The resulting system made relationships possible for Prekomurje and for Podravska with the Austrian lands which meant the largest market of agricultural products produced in Slavonia along the Drava and the South Transdanubian areas..$^{13}$ In addition it also strengthened the western and southern trade relation system of Pécs. "Most strands of economic life directed the city towards the Balkan and the seaport town of Fiume."14

\section{Figure 2. The railway lines of the Free Imperial, Royal Southern Railway Company (Southern Railway)}

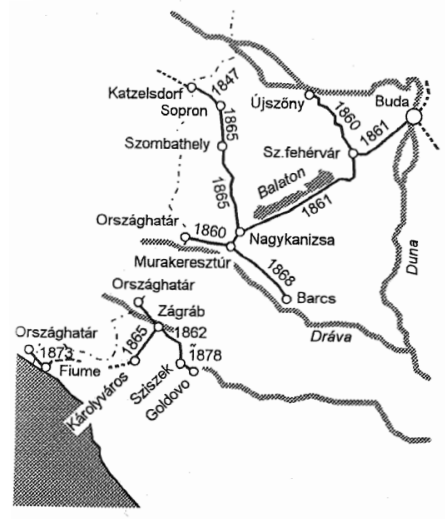

6. äora. Cs.kir.szab. Déli Vaspályatársaság (Déli Vasút)
Source: Ferenc Horváth, Magyarországi Vasúttársaságok, in: Vasúthistória Évkönyv, 1997, 15.

7 In German known as Pragerhof; in Hungarian also known as Prágerhof.

8 Lajos RUZITSKA, A magyar vasútépítések története 1914-ig., Budapest 1964, 16.

9 In Hungarian known as Dálja.

10 Today Богојево / Bogojevo in Serbia; in Hungarian known as Gombos.

11 In Hungarian known as Zombor.

12 János MAJDÁN, Pécs, mint közlekedési központ (1846-1946), in: Mozaikok Pécs és Baranya gazdaságtörténetéből, Pécs 2005, 55-83; Ferenc ERDŐSI, Baranya közlekedési hálózatának fejlődése a XIX. század második felében, Pécs 1986, 383-416.

13 Klára T. MÉREY, Dél-Dunántúl iparfejlődése a dualizmus idején, in: Somogy megye múltjából, Pécs 1979, 265-306.

14 MAJDÁN, 61. 
The increasing socio-economic development and the enhancing of competitiveness with core areas made the further infrastructure development of areas lacking a railway inevitable. Thus the Bátaszék - Dombóvár - Zákány railway was built in 1873 owned by the Danube-Drava Railway Co. track with which a modern transport connection was established with the Great Plain. ${ }^{15}$

In Croatia the railway development first began in the central areas of the country. In 1860 the Kotoriba ${ }^{16}$ - Cakovec ${ }^{17}$ - Pragersko line was built, followed by the Zagreb - Karlovac ${ }^{18}$ section in the summer of 1865 , both of which were owned by the Southern Railway Company. The Kotoriba - Pragersko section provided the accession of western areas of Croatia to the Trieste - Pragersko -Graz - Vienna main line. With the Zákány - Zagreb line which opened in 1872 Western Croatia was integrated into the Austro-Hungarian Empire's existing rail network. ${ }^{19}$ By the expansion of the Zagreb - Karlovac line until Rijeka in 1873, a fast connection to the sea became possible both for Croatia and Hungary. Eastern Slavonia was linked to South Transdanubia with the aforementioned Dalj - Osijek - Villány - Pécs line. The South Slavonian part of the country was integrated to the capital by the Vinkovci - Slavonski Brod ${ }^{20}$ - Novska - Sisak ${ }^{21}$ with the Zagreb - Sisek railway opened in 1862. North Slavonia did not have a main railway line. The vicinal trains disconnecting from the Southern Railways provided connection to the main lines. One of the key features of the Croatian Railway developed by the $20^{\text {th }}$ century was Zagreb-centric and sea oriented. Slavonia was missing North-South direction main lines - these were partially replaced by vicinal trains made up for the commuter.

It can be stated that the railway infrastructure built by 1918 was strongly west-southwest-oriented and capital-centric. The smartening of river transport facilitated the strengthening of economic relations of riparian areas. In addition, the building-up of the rail traffic at a European level increased gaining access of the Carpathian Basin to foreign markets. The Hungarian development policy was consciously aiming to do so. The traffic of the port of Rijeka "in 1913 reached 2.1 million tons, thus gained the $10^{\text {th }}$ place among European ports despite the unfavourable natural conditions and as a result of public investments it could achieve competitiveness". ${ }^{22}$

15 MAJDÁN, 55-83.

16 In Hungarian known as Kotor.

17 In Hungarian known as Csáktornya.

18 In Hungarian known as Károlyváros.

19 RUZITSKA, 16.

20 In Hungarian known as Bród.

21 In Hungarian known as Sziszek.

22 Lóránt BALI, The Historically Changing Role of Port Rijeka in the Hungarian Context (1719-1941), with a Special View on Trieste, in: Central European Papers, 1, 2013, 2, 23-28. 


\begin{tabular}{r|cr}
164 & $\begin{array}{c}\text { ARTICLES } \\
\text { Lóránt BALI }\end{array}$ & $\begin{array}{r}\text { The Role of the Railway in Regional Development in Austro-Hungary and in Hungarian-Groatian } \\
\text { Relations Today, Especially with Regard to the Availability of Rijeka [Fiume] }\end{array}$
\end{tabular}

\section{Present situation}

In terms of Hungary-Rijeka relations, the V / C corridor is the fastest, the Budapest Székesfehérvár - Balaton - Nagykanizsa - Gyékényes line. ${ }^{23}$ The modernization of the railway section of Budapest - Dombóvár is a real chance over the next ten years. However, in areas close to the border it is unfortunately not expected (Pécs - Villány - Magyarbóly and Szigetvár - Barcs - Gyékényes). The Croatian partner has started the renewal Koprivnica24 - Zagreb - Ogulin - Rijeka line and its preparation as well. The lines are disadvantageous in the Rijeka - Lokove section as the stretch is 800 meters. The track of the lines follows the benefits of "nature" as much as possible. Therefore it is sinuous, suffering from the lack of tunnels and very slow. It possesses $50-60 \mathrm{~km} / \mathrm{h}$ on a single track.

Among the three railway crossings Gyékényes must be emphasized, which lies on the $\mathrm{V} / \mathrm{B}$ corridor. The Zagreb - Koprivnica adjoining section is in the best state among the Croatian railway main lines which provides good access to Rijeka and Venice. Magyarbóly has conducted International Traffic towards Bosnia and Herzegovina from its re-opening on 4 September 1997. In what way could we foster the cohesion of the assumed spatial axis, the Pécs - Osijek - Tuzla line? One of the most important means for this is to improve transport facilities among which the improvement of the railway has to face the biggest obstacles. The railway policy of Hungarian governments so far was not strong enough - they were just trying to prevent a deterioration of the quality of service on the medium term. Only the Pécs - Magyarbóly section has a realistic chance of improvement. Based on the prior plans it should be developed for $120 \mathrm{~km} / \mathrm{h}$ speed. The development of locally-based regional railways has only a slight chance. However it could be solved within the framework of other complex touristic, economic development projects.

In terms of the Međimurske and Zala counties and also in the area of Lendava (opcina) there is an untapped alternative development. Between Lendava ${ }^{25}$ and Rédics only a few kilometres short section of line is missing between to engender the Lenti - Rédics - Lendava - Mursko Središće ${ }^{26}$ relation. As a further development of the idea it gives food for thought that after such an investment what legitimacy would a train circling on a Nagykanizsa Murakeresztúr - Kotoriba - Čakovec - Mursko Središće - Lendava - Lenti - Zalaegeszeg - Nagykanizsa "euroregion" line get that could also bring the Burgenland areas closer.

On the Croatian side the Koprivnica - Osijek section binds the Croatian border areas but not any transition can be found which could create a relationship with the Pécs - Gyékényes section. Additionally, in parallel with the Hungarian section running in line with the border the Koprivnica - Kloštar - Našice - Osijek is only a regional and not a primary section. The fast and intercity trains only use it in the Zagreb - Osijek direction!

23 At present there is neither international passenger traffic nor heavy traffic at the Murakeresztúr crossing point. It is only used temporarily in the direction of Croatia.

24 In Hungarian known as Kapronca.

25 In Hungarian known as Ledva.

26 In Hungarian known as Muraszerdahely. 


\title{
Summary
}

The $355 \mathrm{~km}$ of the Croatian-Hungarian border's coverage with railway lines is average in the Eastern European context. However, the number of rail transitions and crossing points is very low. This can be explained by several factors. From Trianon until the solidification of state socialism some local interest micro-regional railway lines with a smaller traffic have been abolished. In a number of cases this resulted in the explosion of a Drava bridge for example between Zaláta and Čađavica and between Barcs and Virovitica ${ }^{27}$ during the Second World War. The biggest problem was caused by the estrangement with Tito's Yugoslavia, which set back the rebuilding of bridges. The Hungarian railway relations towards Rijeka were peculiar. After the Treaty of Trianon, Hungary tried to open towards the Black Sea on the Danube and then on the basis of the cooperation with the state socialist Yugoslavia it managed to get out to sea again through Rijeka. However, the Yugoslav development policy, including the improvement of Koper, achieved that after the regime change, the Hungarian government's development policy diverted the Hungarian traffic towards the city that can be reached faster on a double track, and this was also facilitated by the Zalalövő - Bajánsenye - Őrihodos rail built in 2010.

\begin{abstract}
In the Austro-Hungarian Monarchy the role of the railway was decisive in regional development as well as in the areas of the Hungarian Kingdom, the Pannonian Croatian areas and concerning the accessibility of the Adriatic Sea. During the $19^{\text {th }}$ and $20^{\text {th }}$ centuries the iron horse gave the chance for the quick development of the port of Fiume. At present in terms of Croatian-Hungarian relations on the micro regional level the role of the railway is evanescent concerning regional development. Only the Koprivnica-Zagreb-Rijeka railway line transacts Hungarian heavy traffic. The aim of my study is to present and compare the characteristics of the two eras from the point of view of transport and regional policy.
\end{abstract}

\section{Keywords}

regional development, railway, Rijeka, sea access

\section{References}

BALI, Lóránt: The Historically Changing Role of Port Rijeka in the Hungarian Context (17191941), with a Special View on Trieste, in: Central European Papers, 1, 2013, 2, 23-28.

BELUSZKY, Pál: Őrség-Vendvidék Felső-Rába-Völgye: Szentgotthárd és Környéke, Budapest-Pécs 2005.

ERDŐSI, Ferenc: Baranya közlekedési hálózatának fejlődése a XIX. század második felében, Pécs 1986.

HORVÁTH, Ferenc: 125 éves a volt Alföld-Fiume Vasúttársaság Nagyvárad-Eszék-Villány vonala, in: Vasúthistória Évkönyv, Budapest 1995, 233-277.

27 In Hungarian known as Verőce. 
HORVÁTH, Ferenc: Magyarországi Vasúttársaságok, in: Vasúthistória Évkönyv, Budapest 1997, 7-41.

MAJDÁN, János: Pécs, mint közlekedési központ (1846-1946), in: Mozaikok Pécs és Baranya gazdaságtörténetéből, Pécs 2005, 55-83.

MÉREY, Klára T.: Dél-Dunántúl iparfejlődése a dualizmus idején, in: Somogy megye múltjából, Pécs 1979, 265-306.

RUZITSKA, Lajos: A magyar vasútépítések története 1914-ig., Budapest 1964. 